\title{
DECORATIVE APPLICATION WITH LION'S IMAGE FROM THE EXCAVATIONS NEAR VILLAGE MIZHGIRYA (VOLHYN REGION)
}

\author{
Oleksandr SILAIEV (iD \\ Scientific Research Centre «Rescue Archaeological Service», \\ Institute of Archaeology, National Academy of Sciences of Ukraine, \\ Vynnychenko Str., 24, 79008, Lviv, Ukraine, \\ e-mail:silayevs@ukr.net
}

The article is explaining a unique bronze application, which was discovered during the excavation season 2017 on Mizhgirya-3 site - two-layered settlement of Early Iron Age and Age of Principalities. This item was uncovered amid the upper earth sediments, largely destroyed by plowing, thus making it impossible to determine the exact chronological interpretation.

Based on the analysis of creative stylistics and technological features of this piece of craftsmanship, an excessive pursuit was commenced for the parallels in the imageries and designs of decorative ornaments, particularly inherent to Ancient Rus culture. It includes various examples of zoomorphic motifs, lion's pictures as well, in the church architectural décor and on similar samples of ornamented jewelry. The closest stylistic equivalence to the application's image from Mizhgirya-3 site was found among decorative ceramic tiles collected during the excavations of ancient Halych hill-fort, some of them holding the image of a lion or a lioness. Particular attention was turned towards the searches of analogies among jewelry, applying specific techniques of openwork metal casting, like some items from the excavations of the Ancient Rus' major cities of Halych and Novgorod, found inside cultural sediments from the $12^{\text {th }}-$ to the $15^{\text {th }}$ centuries.

Comparative analysis of various objects, either depicting similar visual motifs or applying the distinctive metal casting technique, made it possible to verify the application's origin at the later stages Age of Principalities cultural evolution, especially the one determined by the advance of Galicia and Volhynia state. Henceforth, the items discovery became more relevant with the upper chronological layer of Mizhgirya-3 site, which was dated by $12^{\text {th }}-13^{\text {th }}$ centuries after the evaluation of supplemented materials.

Key words: bronze decorative application, openwork metal casting, Age of Principalities, zoomorphic motif, «lion passant».

In 2017 expedition of the Scientific Research Centre «Rescue Archaeological Service» (Institute of Archaeology, NASU) has conducted excavations on an ancient settlement Mizhgirya-3 which hold cultural remains of two periods, one of Early Iron Age and another of the Ancient Rus' Age of Principalities $\left(10^{\text {th }}-13^{\text {th }}\right.$ centuries) [Сілаєв, 2018a, c. 17-35].

This site is situated near village Mizhgirya (Lokachi district, Volhyn region), on the north bank of a large pond at a distance of about $1 \mathrm{~km}$ north of old farm buildings (fig. 1). It used to be a settlement on a small island in the middle of the narrow floodplain, adjacent to the source of the spring which flew towards river Luha (Western Bug tributary).

Excavation area of $58 \mathrm{sq} . \mathrm{m}$ was positioned in the southern part of the settlement. It has revealed four objects including pit-house, two household pits and rubbish disposal place.

One of the household pits (object 4) contained potsherds relevant to Lezhnytsia type of Early Scythian time culture. Items within the same date amount only 5 percent in the total number of discovered artifacts from Mizhgirya-3 site [Ільчишин, Сілаєв, 2019, с. 168-172]. Instead, the materials of the Age of Principalities make up the vast majority both in cultural earth deposits and inside the objects. The pit-house (object 2) content was determined amid $10^{\text {th }}$ and $11^{\text {th }}$ century's 
period of existence according to classification and the comparative ratio of in-situ pottery forms. Rubbish disposal place was unearthed in the earth deposits above the pit-house. Its date is defined as $12^{\text {th }}-13^{\text {th }}$ centuries based on the predominant number of characteristic forms of utensils. The same applies to large and amorphous household pit (object 3), which was found in the eastern part of excavation area.

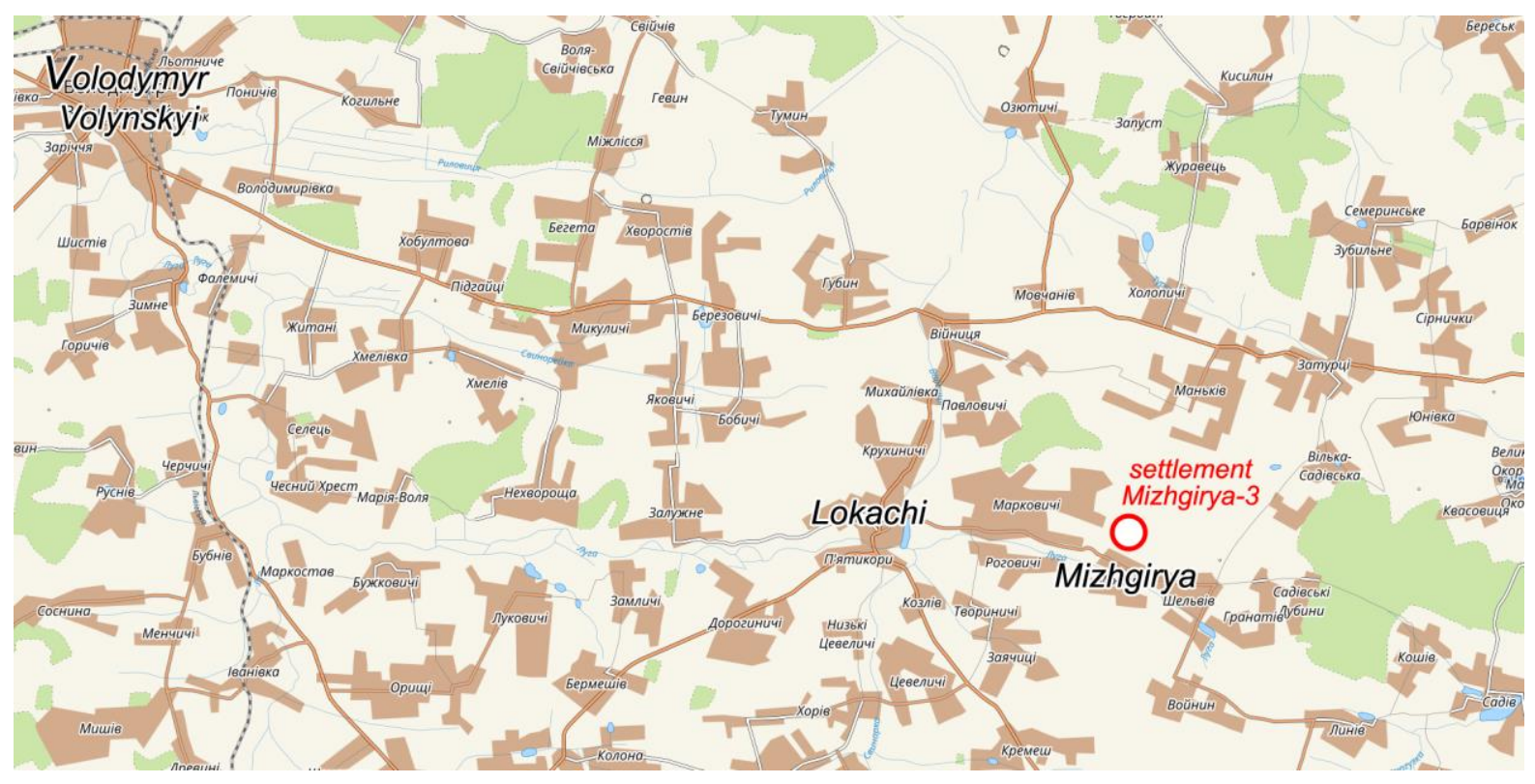

Fig. 1. Situation map of archaeological site Mizhgirya-3

Рис. 1. Ситуативний план археологічної пам'ятки Міжгір'я-3

A unique discovery was made amid the upper layers of cultural earth deposits in the process of sieving. It's a bronze round-shaped application of the distinctive artistic form, $3.2 \mathrm{~cm}$ in width and $0.3 \mathrm{~cm}$ thick, featuring the lion (fig. 2). This item was formed by casting in a one-sided solid matrix of stone or other durable material. Outwards it has embossed figure, encompassed by the circled rim $0.3 \mathrm{~cm}$ wide. Heraldic image of a «lion passant turned leftwards» has modeled muscles and thoroughly portrayed features such as lush mane, tail, claws, ears and eyes. The lion's head is excessively enlarged. Part of the composition beside the rim, from the mouth of the lion to his front leg, is complemented by a plant garland or palmette. Between the parts of the image, there are through holes that were formed in the process of casting. The circular rim has a tapered edge towards the obverse side, and its surface is decorated on top with frequent straight notches. The reverse side of the application is flat and smooth. There were four fastening pins, placed in symmetric order on the edge of the back surface, however broken and grinded so that they protrude only $0.5 \mathrm{~mm}$ downwards. It can be assumed that initially this item has served as an application for a belt or bag, but, with the fastening pins broken, it became utilized as a pendant or as a sewn-on badge. There are, though, no traces of mounted suspension.

Artifact has been found $0.2 \mathrm{~m}$ deep under the grass directly over the household pit fillings of object 3 , which has established dating of the $12^{\text {th }}-13^{\text {th }}$ centuries. Unfortunately, upper soil layer may be destroyed by plowing so that any artifacts in such depth could be brought from other parts of the settlement. Thus, the location of the item in some way gives a hint on the Age of Principalities timespan, but there is still demand for the further definition of the exact chronology and genesis of this product.

Mizhgirya-3 excavation site has granted decent collection of medieval materials in addition to pottery. There are items made of silver, bronze, iron and stone, such as lunula pendants, belt buckles, 
piece of ornamented buckle's plate, wired ring, plane signet ring, body cross made of pyrophyllite slate, arrowheads, knives, nails, fishing hook and more. Some items were dated to the $10^{\text {th }}-11^{\text {th }}$ centuries; others are attributed to the $12^{\text {th }}-13^{\text {th }}$ centuries. However, most of them had been extensively circulating within this chronological range [Сілаєв, 2018b, с. 144-146, рис. 17].

Therefore, in order to establish the age of application with the lion's image, thorough comparative studies should be applied considering the stylistic aspects and the close equivalence among the relics of Kyivan Rus' and surrounding realms.
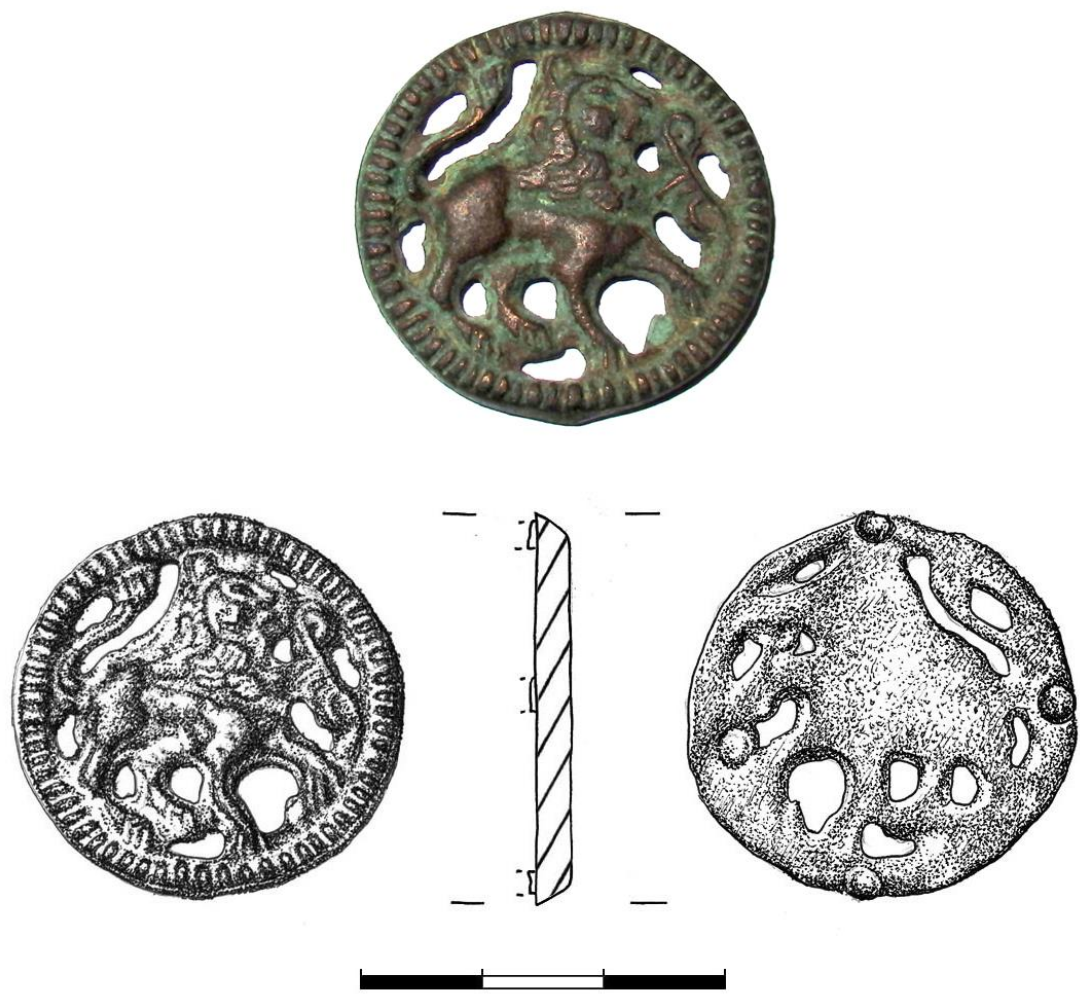

Fig. 2. Bronze Application from Mizhgirya-3 settlement (Lokachi district, Volhyn region)

Рис. 2. Бронзова накладка з поселення Міжгір'я-3 (Локачинський район, Волинська область)

Images of animals and mythical creatures are quite common among the decorative patterns innate to Rus' culture. The largest number of such sculpture themes could be observed on the architectural décor of $11^{\text {th }}-13^{\text {th }}$ century temples, such as the wall carvings on the churches of Vladimir - Suzdal Principality erected prior to the Mongol invasion [Вагнер, 1969], the fragments of moldings from Chernihiv Boris-and-Gleb Cathedral [Коваленко, Пуцко, 2012, c. 79-84], and the ornamental brick plates from the excavations of ancient Halych hill-fort [Пастернак, 1998, с. 96, рис. 60; Гончаров, 1955, с. 29-30, табл. 2; Малевская, Раппопорт, 1978, с. 87-97].

There were various researcher attempts to establish the origins of such designs under the influence of Byzantine culture and of the Romanesque architecture of Northern Italy [Пуцко, 2007, c. 278-279; Архипова, 2012, р. 25; Малевская, Раппопорт, 1978, с. 95-96; Кошовий, 1998, с. 170 175]. Yet, in late $11^{\text {th }}$ to early $12^{\text {th }}$ centuries, Rus principalities witnessed birth of indigenous architectural traditions which have widely applied plastic décor picturing plants, animals, and mythical creatures [Балабушка, 2016, с. 67-68]. By means of religious fine art, such imaginary motifs penetrated into the sphere of everyday life culture of the Age of Principalities and become its integral part. 
Images of predators and mythical creatures common to ancient Rus' culture could be as well compared in shapes and forms with the metal engravings of the East, especially of Sassanid Iran and succeeding Muslim cultures of the Middle East and Central Asia [Даркевич, 1976, с. 78-80, рис. 6, 9, табл. 7]. Here we have widely stretched in time and space sequence of mutual cultural influences and transferals. Numerous oriental zoomorphic motifs have received artistic reincarnations in the Byzantine and Western European metal casting crafts, and those, in turn, have influenced development of relevant cultural tradition in First Bulgarian State, Great Moravia, Hungary and Ancient Rus' [Матвеев, 2017, с. 384-385; Doncheva, 2012, p. 102-103]. And once again these effects were revamped and transformed into original regional cultural trends.
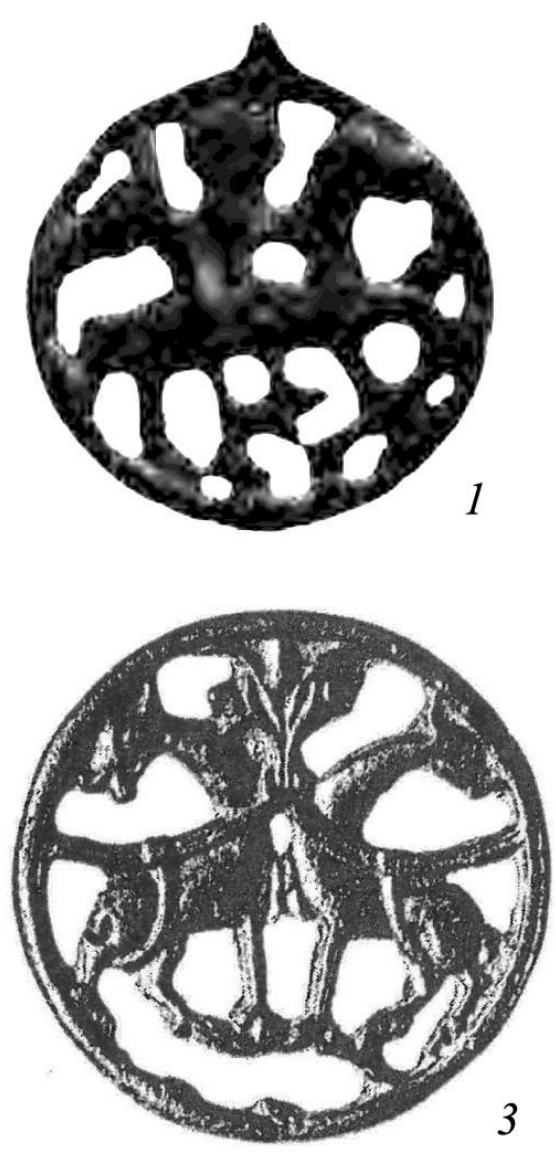
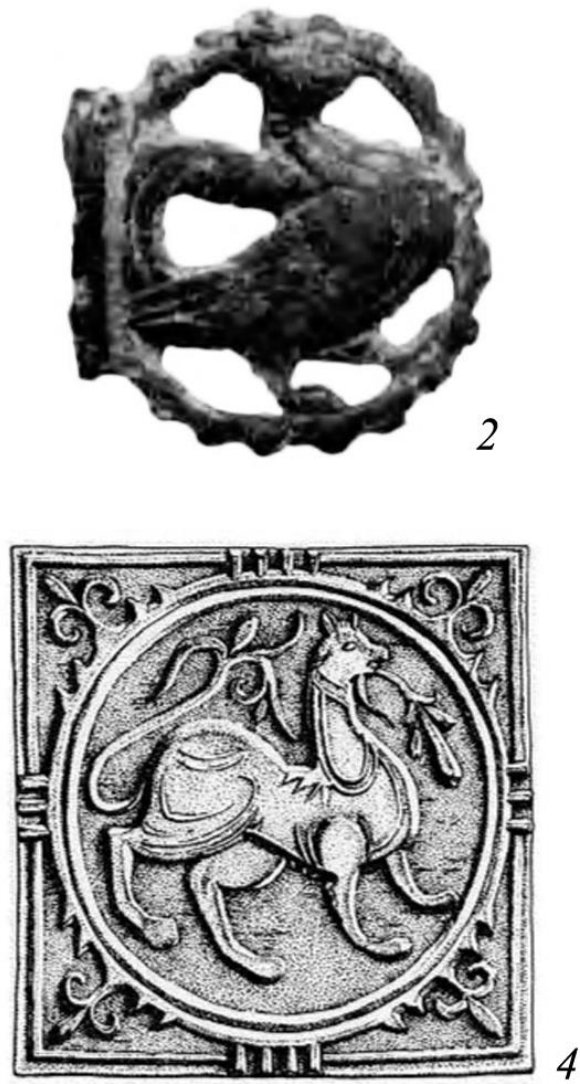

Fig. 3. Samples of openwork metal casting: 1, 2 - ancient Halych hill-fort (Коваль, Миронюк, 2015, с. 131, 302); 3 - Novgorod (Sedova, 1981, p. 167-168, fig. 69) and 4 - the lion-s image on decorative ceramic tiles from ancient Halych (Малевская, Раппопорт, 1978, с. 94)

Рис.3. Зразки зооморфної ажурної металопластики: 1, 2 - городище давнього Галича (Коваль, Миронюк, 2015, с. 131, 302); 3 - Новгород (Седова, 1981, с. 167-168, рис. 69) та 4 - зображення лева на керамічних плитках з давнього Галича (Малевская, Раппопорт, 1978, с. 94)

Jewelry items of Ancient Rus' origin were frequently decorated with zoomorphic motifs. However, the appearance of a lion or a leopard is not the most common among them, nothing like the images of birds and griffins. The latter can often be seen on the casement bracelets, kolts and signet rings [Макарова, 1986, с.16-17, рис. 6, 7]. The parallels, closest in distance, should be seen among the collection of bracelets with the repeating images of birds and the "Tree of Life», which were found in several treasures of $13^{\text {th }}-14^{\text {th }}$ centuries across the regions of Lviv (Sokal town and village Demydiv in Mykolaiv district), Khmelnytskyi (Bozhsk hill-fort near village Horodyshche, Derazhnia district) 
and Ivano-Frankivsk (vil. Viktoriv, Halych district), as well as on the territory of Lithuania and Moldova [Багрій, Петегирич, 1993, с. 44; Даркевич, Соболева, 1973, с. 84-85, рис. 1, 2]. These artifacts were referred to as an exclusive «Galician type», distinguished by its somewhat clumsy graphics and simplified stylistics [Волощук, 2018, с. 12-13, рис. 1-5].

At the same time, there exists a variety of jewelry forms adorned with significantly more detailed animal appearances. Such are the silver kolts with griffin images, found on Ancient Rus' hillfort near vil. Terepcza (Sanok county, Subcarpathian voivodeship, Poland) and placed in the collection of Sanok Historical Museum [Ginalski, 2001, s. 133-135]. Alternatively, close semblance of leopard can be seen on the disk-shaped pendant, dated around the $13^{\text {th }}-14^{\text {th }}$ centuries, which was found in Borshchiv district of Ternopil region [Ягодинська, 2010, с. 244, рис. 10, 6]. Several casting molds with imprinted bird figures were discovered in Sub-Carpathian area, thus comprising the direct proof of local production of such jewelry kind. A copper matrix, designed for the manufacturing of kolts, was found in the earth deposits of the $12^{\text {th }}$ century during the excavation of ancient Holm [Буко, Дзеньковський, Голуб, 2001, с. 188-189]. Also, a bilateral stone mold was discovered in the locality Yuriivske Monastyryshche inside ancient Halych hill-fort [Пастернак, 1998, с. 206, рис. 60, 3].

Imprinted images of birds and animals, including lions, could be often found on signet of the Age of Principalities. Some of them were found by private collectors, in treasures, and during the excavations, particularly in Novgorod [Седова, 1981, с. 137-139, рис. 52, 53], Нalych [Коваль, Миронюк, 2015, с. 282], on ancient Bozhsk hillfort near village Horodyshche, Derazhnia district, Khmelnytskyi region) [Якубовский, 2003, с. 60-65, рис. 36-37], and on Shatsk hillfort of $12^{\text {th }}-14^{\text {th }}$ in Volhyn region [Демидюк, 2018, с. 1]. Due to the small size of such products, the animals were depicted in less detail; nonetheless they had their figure stamped in embossed protrusion.

Lion, pictured on the application from Mizhgirya-3 settlement, has its figure carved with much more embellished details and with an overall realistic approach, comparing to all noted samples.

That is why we have to pay attention to somewhat peculiar technique in which this piece of jewelry was created, namely openwork metal casting. It has distinctive feature of final products which include see-through gaps between segments of the composition. Items were mostly manufactured by casting metal inside one or two part stone molds. The example of jewelry crafting tools, collected from the excavations of Novgorod, testifies that such devices did not appear earlier then the late $11^{\text {th }}-$ early $12^{\text {th }}$ century [Рындина, 1963, c. 218].

There exist a significant number of items produced by this technique, pendants for the most part. They were disk-shaped, bordered by a circular rim and supplemented with a certain figure inside, most often depicting geometric compositions, Christian symbols or other religious concepts [Седова, 1981, с. 37, рис. 10, 1, 2, 12; Коваль, Миронюк, 2015, р. 75, 77; Ягодинська, 2010, с. 243, рис. 10, 5]. Certain products hold us well the portraits of Christian saints, floral or animal images. For example, a very similar technique was applied to the jewelry detail depicting jackdaw (fig. 3, 2) [Коваль, Миронюк, 2015, с. 131], or to pendant icon of St. George and the Dragon (fig. 3, 1) [Коваль, Миронюк, 2015, с. 297, 302], both of them found on the ancient Halych hill-fort. Two other bronze applications, implying openwork metal casting, were discovered as a result of excavation in Novgorod. One of them dates from the turn of the XIII-XIV centuries. It has a trapezoid form encasing the reflected image of two leopards and a lion cub. [Седова, 1981, с. 165, рис. 67]. Another one was found in the deposits of mid- $15^{\text {th }}$ century. Disc-shaped artifact depicted symmetrically placed animals alongside the "Tree of Life» (fig. 3, 3). The last item was viewed by various scientists as a reflection of influence from Late Byzantine [Седова, 1981, с. 167, 168, рис. 69] or Golden Horde cultures [Козлова, 2004, с. 203-204, рис. 7], given the similar elements in image composition.

Mutual penetration of iconographic traditions from the elements of church architectural décor and jewelry items was testified in all parts of Ancient Rus', as well as the comparable tendencies in the evolution of ornamental motifs. For example, N. Zhylina has demonstrated, analyzing the evolution of images from the stone carvings and jewelry in Northern Rus' Principalities, the tendency of transition from the laconic and stylized forms, typical in $11^{\text {th }}-12^{\text {th }}$ centuries, to more «living», 
detailed and proportional images of the first third of $13^{\text {th }}$ century [Жилина, 2016, с. 129-136, рис. 1, 2,3]. Similarly, within the fine arts evolution of the material culture in Halych city and in the entire Halych principality some researchers notice the birth of a distinctive «animalistic style», especially relevant to the architectural ornamentation and jewelry craft. [Білик, 2017, с. 70-73].

Therefore, it is appropriate to see the closest analogue to the lions image on the applications from Mizhgirya-3 settlement among the decorative ceramic tiles which were discovered during excavation of ancient Halych hill-fort, partially inside the structures of $12^{\text {th }}-13^{\text {th }}$ centuries and more frequently in the upper earth deposits without proper allocation [Малевская, Раппопорт, 1978, с. 91; Ляска, Мінейко, Вітвіцька, 2009, с. 177-178, рис. 3, 2]. Some of these tiles were stamped with the image of lion or lioness inside the circular casing (fig. 3,4). Both images on application and on the ceramic tiles demonstrate the set of common features, such us walking posture, muscle details, dynamics of movement with tense expression, attached plant palette near the mouth of the beast.

Such and other parallels in the formal motifs and design, as well as specific metal casting techniques, determine the date of the application within the late period of the Age of Principalities. This statement does coincide with the actual allocation of the artifact alongside the upper cultural sediments on the settlement Mizhgirya-3, which were dated by $12^{\text {th }}-13^{\text {th }}$ centuries after the analysis of other materials.

The image of lion has undoubtedly special significance as the symbol of the Kingdom of Galicia and Volhynia in the second half of the $13^{\text {th }}-14^{\text {th }}$ centuries. Starting with the rule of Lev Danylovych it has become in fact the element of royal coat of arms. The «lion passant» was depicted on the seals of last Ruthenian rulers of the kingdom [Грушевський, 1990, с. 123, рис. 110].

Quite possible the piece of decorated warrior's equipment with such symbolic image may has occurred $30 \mathrm{~km}$ away of Volodymyr - capital of Volhynia principality, some $6 \mathrm{~km}$ to the east of Lokachi hill-fort, should it be coinciding with the later stages of Galicia and Volhynia state history.

\section{LITERATURE}

Архипова, Е. (2012). Романская архитектурная резьба Борисоглебского собора в Чернигове. Матеріальна та духовна культура Південної Русі. Матеріали Міжнародного польового археологічного семінару, присвяченого 100-літтю від дня народження В.Й. Довженка, 16-19 липня 2009 р. (с. 25-35). Київ-Чернігів.

Багрій, Р., Петегирич, В. (1993). Скарб срібних виробів княжої доби із Сокаля на Львівщині. Studia archeaologica, 1, 42-44.

Балабушка, В. (2016). Соціалізація середньовічних європейських традицій архітектури Чернігова. Науковий часопис Національного педагогічного університету імені М.П.Драгоманова. Серія 7: Релігієзнавство. Культурологія. Філософія, 36(49), 61-71.

Білик, О. (2017). Образ грифона в галицькому середньовічному мистецтві. Мистецтвознавчі записки, 32, 67-76.

Буко, А., Дзеньковський, Т., Голуб, С. (2001). Холм доби Данила Романовича у світлі результатів найновіших розкопок. Галичина та Волинь в добу середньовіччя. До 800-річчя з дня народження Данила Галицького (с. 187-191). Львів.

Вагнер, Г. (1969). Скульптура Древней Руси. Москва.

Волощук, М. (2018). Галицькі князі та знать у відносинах із Литвою XII-XIV ст. Украӥнський історичний журнал, 4(541), 4-19.

Гончаров, В. (1955). Археологічні дослідження древнього Галича у 1951 р. Археологічні пам'ятки УРCP, 5, 22-31.

Грушевський, М. (1990). Ілюстрована історія України. Київ.

Даркевич, В. (1976). Художественный метал Востока. Москва.

Даркевич, В., Соболева, Н. О датировке литовських монет с надписую «печать» (по матеріалам Шанчайского клада). Советская археология, 1(65), 83-95.

Демидюк, С. (2018, 21 серпня). На Шацьких озерах знайшли «крилатих вовків». Волинь, 61 (16456), $1,8$. 
Жилина, Н. (2016). Стилистические параллели: ювелирные украшения, архитектурная резьба и живопись древней Руси. Древняя Русъ. Вопросы медиевистики, 4(66), 129-142.

Ільчишин, 3., Сілаєв, О. (2019). Нові матеріали ранньоскіфського часу в долині р. Луга. Матеріали і дослідження з археологї Прикарпаття і Волині, 23, 154-182. https://doi.org/10.33402/mdapv.2019-23-154$\underline{182}$

Коваленко, В., Пуцко, В. (2012). Кам’яне різьблення в чернігівському Спасі. Чернігівські старожитності, 1(4), 79-84.

Коваль, I., Миронюк, I. (2015). Сучасна археологія княжого Галича та Галицької землі. ІваноФранківськ.

Козлова, А. (2004). Украшения ремня, сбруи и сумок восточного происхождения из раскопок в Великом Новгороде. Новгород и Новгородская земля: история и археология (с. 188-207). Великий Новгород.

Кошовий, О. (1998). Керамічні плитки стародавнього Галича: підходи здалека. Медобори і духовна культура давніх, середньовічних слов'ян. Матеріали наукової конференції, Гримайлів, 8-9 жовтня 1998 р. (с. 170-175). Львів-Гримайлів.

Ляска, В., Мінейко, О., Вітвіцька, Г. (2009). Галицькі керамічні плитки з колекції археологічного музею Львівського університету (матеріали до каталогу). Археологічні дослідження Львівського університету, 12, 169-181.

Макарова, Т. (1986). Черневое дело древней Руси. Москва.

Малевская, М., Раппопорт, П. (1978). Декоративные керамические плитки древнего Галича. Slovenska archeologia, 26-1, 87-97.

Матвеев, В. (2017). Галицкие рельефные плитки: европейский контекст. Актуальные проблемы теории и истории искусства, 7, 384-397.

Пастернак, Я. (1998). Старий Галич: археологічно-історичні досліди у 1850-1943рр. ІваноФранківськ.

Пуцко, В. (2007). Чернігів в історії візантійсько-руського сакрального мистецтва. Чернігів $y$ середньовічній та ранньомодерній історії Центрально-Східної Європи: Збірник наукових праць, присвячених 1100-літтю першої літописної згадки про Чернігів (с. 278-286). Чернігів.

Рындина, Н. (1963). Технология производства новгородских ювелиров X-XV вв. Материалы $u$ исследования по археологии СССР, 117, 200-263.

Седова, М. 1981. Ювелирные изделия Древнего Новгорода (X-XV вв.). Москва.

Сілаєв, О. (2018а). Звіт про пам'яткоохоронні роботи під час облаштування Локачинського газового родовища на території Волинської області у 2017 році. Науковий архів Науково-дослідного центру «Рятівна археологічна служба» Інституту археології Національної академії наук України. Львів.

Сілаєв, О. (2018b). Дослідження двошарового поселення Міжгір'я-3. Вісник рятівної археологіі (Acta Archaeologiae Conservativae), 4, 139-165.

Ягодинська, М. (2010). Ювелірні вироби з давньоруських пам'яток Західного Поділля (за матеріалами Тернопільської області). Археологія і давня історія Украӥни, 2, 235-248.

Якубовский, В. 2003. Скарби Болохівської землі. Кам'янець-Подільський.

Doncheva, S. (2012). Metal Art Production in Medieval Bulgaria. Jewelry craftsmanship in Bulgaria at the Middle Ages. Saarbrücken.

Ginalski, J. (2001). Para srebrnych ozdób kobiecego nakrycia głowy tzw kołtów z grodziska «Horodyszcze» w Trepczy, gmina Sanok, stanowisko 2. Acta Achaeologica Carpathica, 36, 133-148.

\section{REFERENCES}

Arkhipova, E. (2012). Romanskaia arkhytekturnaia rezba Borysohlebskogo sobora v Chernygove. Materialna ta dukhovna kultura Pivdennoi Rusi. Proceedings of the International field archaeology seminarium, dedicated to the 100 th Anniversary of V.I. Dovzhenko, Chernihiv - Shestovytsia, 2009, July 16-19 (pp. 25-35). Kyiv-Chernihiv. (in Russian).

Bahrii, R., \& Petehyrych, V. (1993). Skarb sribnykh vyrobiv kniazhoi doby iz Sokalia na Lvivshchyni. Studia archeaologica, 1, 42-44. (in Ukrainian). 
Balabushka, V. (2016). Sotsializatsiia serednovichnykh yevropeiskykh tradytsii arkhitektury Chernihova. Naukovyi chasopys Natsionalnoho pedahohichnoho universytetu imeni M. P. Drahomanova. Seriia 7: Relihiieznavstvo. Kulturolohiia. Filosofiia, 36(49), 61-71. (in Ukrainian).

Bilyk, O. (2017). Obraz hryfona v halytskomu serednovichnomu mystetstvi. Mystetstvoznavchi zapysky (Notes on Art Criticism), 32, 67-76. (in Ukrainian).

Buko, A., Dzieńkowski, T., \& Golub S. (2001) Kholm doby Danyla Romanovycha u svitloi rezultativ nainovishykh rozkopok. Halychyna ta Volyn $v$ dobu serednovichchia. Do 800-richchia $z$ dnia narodzhennia Danyla Halytskoho (pp. 187-191). Lviv. (in Ukrainian).

Vagner, G. (1969). Skulptura Drevney Rusi. Moskva. (in Russian).

Voloshchuk, M. (2018). Halytski kniazi ta znat u vidnosynakh iz Lytvoiu XII-XIV st. Ukrainskyi istorychnyi zhurnal (Ukrainian Historical Journal), 4(541), 4-19. (in Ukrainian).

Goncharov, V. (1955). Arkheolohichni doslidzhennia drevnoho Halycha u 1951 r. Arkheolohichni pamiatky URSR, 5, 22-31. (in Ukrainian).

Hrushevskyi, M. (1990). Iliustrovana istoriia Ukrainy. Kyiv. (in Ukrainian).

Darkevych, V. (1976). Khudozhestvennyi metal Vostoka. Moskva. (in Russian).

Darkevych, V., \& Soboleva, N. (1973). O datirovke litovskikh monet s nadpisyu «pechat» (po materialam Shanchaiskogo klada). Sovetskaia arkheologiya, 1 (65), 83-95. (in Russian).

Demydiuk, S. (2018, August 21). Na Shatskykh ozerakh znaishly «krylatykh vovkiv». Volyn, 61(16456), 1, 8. (in Ukrainian).

Zhylyna, N. (2016). Stilysticheskie paralleli: yuvelirnyie ukrashenyia, arkhitekturnaya rezba i zhyvopis drevney Rusi. Drevniaya Rus. Voprosy medievystiki, 4(66), 129-142. (in Russian).

Ilchyshyn, Z., \& Silaiev, O. (2019). Novi materialy rannoskifskoho chasu v dolyni r. Luha. Materials and studies on archaeology of Sub-Carpathian and Volhynian area, 23, 154-182. https://doi.org/10.33402/mdapv.2019-23-154-182 (in Ukrainian).

Kovalenko, V., \& Putsko, V. (2012). Kamiane rizblennia v chernihivskomu Spasi. Chernihivski starozhytnosti, 1(4), 79-84. (in Ukrainian).

Koval, I., \& Myroniuk, I. (2015). Suchasna arkheolohiia kniazhoho Halycha ta Halytskoi zemli. IvanoFrankivsk. (in Ukrainian).

Kozlova, A. (2004). Ukrasheniya remnia, sbrui i sumok vostochnogo proiskhozhdeniya iz raskopok v Velikom Novgorode. Novgorod i Novgorodskaya zemlia: istoryiya $i$ arkheolohiya (pp. 188-207). Veliky Novhorod. (in Russian).

Koshovyi, O. (1998). Keramichni plytky starodavnoho Halycha: pidkhody zdaleka. Medobory i dukhovna kultura davnikh, serednovichnykh slovian. Proceedings of Scientific Conference, Hrymailiv, 1998, October 8-9 (pp. 170-175). Lviv. (in Ukrainian).

Liaska, V., Mineiko, O., \& Vitvitska, H. (2009). Halytski keramichni plytky z kolektsii arkheolohichnoho muzeiu Lvivskoho universytetu (materialy do katalohu). Arkheolohichni doslidzhennia Lvivskoho universytetu (Lviv university archaeology studies), 12, 169-181. (in Ukrainian)

Makarova, T. (1986). Chernevoe delo drevniey Rusi. Moskva. (in Russian).

Malevskaia, M., \& Rappoport, P. (1978). Dekorativnye keramicheskie plitki drevnego Galicha. Slovenska archeologia, 26-1, 87-97. (in Russian).

Matveev, V. (2017). Galitskye reliefnye plitki: evropeisky kontekst. Aktualnye problemy teorii i istorii iskusstva, 7, 384-397. (in Russian).

Pasternak, Ya. (1998). Staryi Halych: arkheolohichno-istorychni doslidy u 1850-1943 rr. Ivano-Frankivsk. (in Ukrainian).

Putsko, V. (2007). Chernihiv $\mathrm{v}$ istorii vizantiisko-ruskoho sakralnoho mystetstva. Chernihiv $u$ serednovichnii ta rannomodernii istorii Tsentralno-Skhidnoi Yevropy (pp. 278-286). Chernihiv. (in Ukrainian).

Ryndina, N. (1963). Tekhnologiya proizvodstva novgorodskikh yuvelirov X-XVvv. Materialy $i$ issledovaniya po arkheologii SSSR, 117, 200-263. (in Russian).

Sedova, M. (1981). Yuvelirnye izdeliya Drevnego Novgoroda ( $X-X V v v$.). Moskva. (in Russian). 
Silaiev, O. (2018a). Zvit pro pamiatkookhoronni roboty pid chas oblashtuvannia Lokachynskoho hazovoho rodovyshcha na terytorii Volynskoi oblasti u 2017 rotsi. Naukovyi arkhiv Naukovo-doslidnoho tsentru «Riativna arkheolohichna sluzhba» Instytutu arkheolohii Natsionalnoi akademii nauk Ukrainy. Lviv. (in Ukrainian).

Silaiev, O. (2018b). Doslidzhennia dvosharovoho poselennia Mizhhiria-3. Visnyk riativnoi arkheolohii (Acta Archaeologiae Conservativae), 4, 139-165. (in Ukrainian).

Yahodynska, M. (2010). Yuvelirni vyroby $\mathrm{z}$ davnoruskykh pamiatok Zakhidnoho Podillia (za materialamy Ternopilskoi oblasti). Arkheolohiia i davnia istoriia Ukrainy, 2, 235-248. (in Ukrainian).

Yakubovskyi, V. (2003). Skarby Bolokhivskoi zemli. Kamianets-Podilskyi. (in Ukrainian).

Doncheva, S. (2012). Metal Art Production in Medieval Bulgaria. Jewelry craftsmanship in Bulgaria at the Middle Ages. Saarbrücken.

Ginalski, J. (2001). Para srebrnych ozdób kobiecego nakrycia głowy tzw kołtów z grodziska «Horodyszcze» w Trepczy, gmina Sanok, stanowisko 2. Acta Achaeologica Carpathica, 36, 133-148. (in Polish).

Стаття: надійшла до редакції 18.07.2020 прийнята до друку 15.10.2020

\title{
ДЕКОРАТИВНА НАКЛАДКА З ЗОБРАЖЕННЯМ ЛЕВА 3 РОЗКОПОК НЕПОДАЛІК СЕЛА МІЖГІР’Я (ВОЛИНСЬКА ОБЛАСТЬ)
}

\author{
Олександр СІЛАЄВ \\ НДЦ “Рятівна археологічна служба" Інституту археології НАН України, \\ вул. Винниченка, 24, 79008, м. Львів, Україна, \\ e-mail: silayevs@ukr.net
}

Стаття присвячена унікальній бронзовій накладці, яка була виявлена під час розкопок 2017 р. на двошаровому поселенні ранньозалізного віку та княжої доби Міжгір'я-3 в Локачинському р-ні Волинської обл. Локалізована у верхньому орному шарі грунту, знахідка не могла бути однозначно пов'язана з визначеними культурно-хронологічними горизонтами пам'ятки.

На підставі аналізу художньої стилістики та технологічних рис цього предмету проведено пошук широких аналогій серед образів та мотивів декоративних прикрас, особливо притаманних культурі Давньої Русі. Розглянуто приклади використання зооморфних мотивів, в тому числі зображень левів, в оздобленні споруд сакральної архітектури та схожі взірці орнаментування предметів ювелірного мистецтва. Серед найближчих паралелей накладці з пам'ятки Міжгір'я-3 наведено образ лева або левиці, який зустрічається на окремих декоративних керамічних плитках з розкопок княжого Галича. Окремо увагу було зосереджено на пошуку аналогій серед ювелірних виробів, виготовлених з використанням специфічної техніки ажурної металопластики, зокрема серед знахідок з розкопок давньоруських міст Галича та Новгорода, які датуються від XII до XV ст.

Порівняння 3 різними предметами, що мають схожі образні мотиви або виготовлені 3 застосуванням характерної техніки, дозволяє віднести накладку до пізніх етапів розвитку культури княжої доби загалом та Галицько-Волинської держави зокрема. Це в свою чергу, надає підстави співвіднести знахідку із верхнім хронологічним горизонтом пам'ятки Міжгір'я-3, що датується XIIXIII ст.

Ключові слова: бронзова декоративна накладка, ажурна металопластика, княжа доба, зооморфний мотив, «крокуючий лев». 